УДК 378.14:54

\title{
ОРГАНІЗАЦІЯ НАВЧАЛЬНОЇ ДІЯЛЬНОСТІ У ФОРМІ МАЛИХ ГРУП ПРИ ВИВЧЕННІ ХІМІЧНИХ ДИСЦИПЛІН У ВИЩІЙ ШКОЛІ
}

\author{
М. В. Кирилів, І. Р. Бекус, А. Є. Демид
}

ДВНЗ “Тернопільський держсавниймедичний університет імені І. Я. Горбачевського МОЗ Украйни”

\section{EDUCATION ACTIVITIES ORGANIZATION IN FORM OF SMALL GROUPS IN THE STUDY OF CHEMISTRY IN HIGH SCHOOL}

\author{
M. V. Kyryliv, I. R. Bekus, A. Ye. Demyd \\ SHEI "Ternopil State Medical University by I. Ya. Horbachevsky of MPH of Ukraine"
}

\begin{abstract}
У статті наведено основні принципи застосування групової форми організації навчально-пізнавальної діяльності студентів у вищій школі. Викладено особливості формування малих груп для виконання лабораторно-практичних робіт при вивченні хімічних дисциплін, які застосовуються авторами в процесі професійно-педагогічної підготовки майбутніх лікарів.
\end{abstract}

The article presents basic principles of application of group forms of educational-cognitive activity organization of students in high school. The article describes the features of the formation of small groups for laboratory and practical activities in the study of chemistry, which are used by authors in the process of professional training of medical students.

Вступ. Стрімкий науково-технічний прогрес, який відбувається на етапі сьогодення, вимагає ефективної діяльності вищої школи, професійної компетентності і особистісного розвитку її випускників. Це дає поштовх до пошуку шляхів підвищення ефективності навчального процесу, удосконалення вже існуючих напрацювань та розробки нових підходів до навчання та виховання [1]. У цьому вирі наукової інформації формується майбутній фахівець будь-якої галузі, в тому числі і медик. Впродовж навчання у ВНЗ перед майбутнім лікарем стоїть ряд завдань, виконання яких забезпечується педагогічними методами i формами.

Основна частина. Перенесення центру уваги у навчанні на самостійну роботу, на створення умов, які б стимулювали систематичне, активне, самостійне оволодіння знаннями, $є$ характерною ознакою сучасної освіти. Завданням викладача на початкових курсах, де студенти отримують базові знання з різних галузей медицини: анатомії, фізіології, хімії, фармакології та ін., є навчити майбутнього медика не тільки здобувати, а й проводити аналіз і систематизацію навичок та умінь.

На лекціях студенти набувають знання на рівні ознайомлення, на практичних заняттях створюються найбільш сприятливі умови для оволодіння поняттями і закріплення знань на якісно новому рівні-транс-

() М. В. Кирилів, І. Р. Бекус, А. С. Демид формації знань, в ході чого краще осмислюється визначена проблема, набуваються практичні навички використання знань [2].

Вивчення хімічних дисциплін у вищих навчальних закладах передбачає виконання студентами лабораторно-практичних робіт. Одна з важливих переваг лабораторних занять, у порівнянні з іншими видами аудиторної навчальної роботи, полягає в інтеграції теоретичних знань 3 практичними уміннями і навичками студента в єдиному процесі діяльності навчальнодослідницького характеру. Під час виконання лабораторних робіт студенти набувають практичних навичок роботи 3 лабораторним устаткуванням, оснащенням, обчислювальною технікою, вимірювальною апаратурою, опановують методику експериментальних досліджень у конкретній предметній галузі. Виконання лабораторних робіт вимагає від студента творчої ініціативи, самостійності у прийнятті рішень, глибокого знання і розуміння навчального матеріалу, надає можливості стати “відкривачем істини", позитивно впливає на розвиток пізнавальних інтересів та здібностей [3]. Для забезпечення усіх переваг лабораторних робіт ефективним $€$ використання групової форми організації навчання.

Групову навчальну діяльність ми розглядаємо як сукупну навчальну діяльність невеликих за складом груп, що діють у межах однієї академічної групи [2, 4].

Групова навчальна діяльність сприяс активізації й результативності навчання студентів, вихованню 
гуманних стосунків між ними, самостійності, уміння доводити і відстоювати свою точку зору, а також прислухатися до думки товаришів, культури ведення діалогу, відповідальності за результати своєї праці. Групова навчальна діяльність на занятті створює певні умови для формування позитивної мотивації учіння студентів. Як свідчить практика викладачів, під час групової роботи активізується діяльність усіх без винятку її виконавців. Психологи пояснюють це тим, що одна 3 найважливіших характеристик людини в колективі полягає в тому, що вона звертається до своїх одногрупників як до джерела орієнтації у навколишній дійсності. Як вид навчальної діяльності студентів групова діяльність - багатофункціональна. Тут студенти показують високі результати засвоєння знань та формування вмінь [5].

Важливу роль групова діяльність відіграє у досягненні виховних функцій. У груповій навчальній діяльності формуються колективізм, моральні та гуманні якості особистості. Важливу роль у формуванні цих якостей відіграють особливості організації групової роботи; розподіл функцій і обов' язків між учасниками діяльності, обмін думками, взаємна вимогливість і допомога, взаємоконтроль і взаємооцінка. Групова навчальна діяльність виконує й організаційну функцію. Полягає вона в тому, що студенти вчаться розподіляти обов' язки, вчаться спілкування один з одним, розв'язують конфлікти, що виникають у спільній діяльності. Таким чином, групова форма навчальної діяльності, порівняно з іншими організаційними формами, має низку значних переваг: за той самий проміжок часу обсяг виконаної роботи набагато більший; висока результативність у засвоєнні знань і формуванні вмінь; формується вміння співпрацювати; формуються мотиви навчання, розвиваються гуманні стосунки між дітьми; розвивається навчальна діяльність (планування, рефлексія, самоконтроль, взаємоконтроль) [6]. Методом групового навчання $є$ взаємне навчання, яке передбачає, що кожен із тих, хто навчається, є одночасно вчителем стосовно до інших членів групи, допомагає їм засвоїти ті знання та вміння, якими вони володіють найбільш успішно, що сприяє вирівнюванню загального рівня засвоєння студентами навчального матеріалу. Взаємне навчання передбачає спільне засвоєння теоретичного матеріалу, спільне набуття вмінь та навичок, спільний контроль [7].

Студенти однієї академічної групи істотно різняться рівнем навчальних можливостей. Створення дієвих працездатних малих груп слід проводити таким чином, щоб у складі кожної групи було не менше поло- вини учасників з достатнім, для виконання групового завдання, рівнем навчальних можливостей. Крім того, психологічні характеристики студентів, які взаємодіють у групі, мають вплив на ефективність групової діяльності, а тому важливо уникати формального способу створення малих навчальних груп.

Щоб студенти швидше зрозуміли специфіку групового виду навчальної роботи, на початкових заняттях нами здійснюється формальний поділ академічної групи на малі групи. Головним суб'єктом організованої таким чином діяльності залишається викладач. Він проявляє ініціативу в організації діяльності студентів, бере керівництво нею на себе. Продемонструвавши у такий спосіб характерні риси спільної навчальної діяльності у складі малої групи, викладач приступає до створення стабільних, діючих впродовж усього навчального року, гетерогенних навчальних груп.

Перед викладачем, який організовує групи, у першу чергу постає питання про їх кількісний склад. Об'єктивна перевага роботи студентів у групах пов'язана з розширенням можливостей для кожного студента займати активну позицію у процесі навчальної комунікації. Тому бажано, щоб склад групи був мінімальним. У той же час загальна кількість груп має бути невеликою для більшої зручності в керуванні їх роботою. Спеціальні психолого-педагогічні дослідження засвідчують, що оптимальний склад групи - від 2 до 5 осіб, тому що саме у такій групі кожен студент може брати активну участь у спільній роботі [8]. В процесі нашої роботи практикується створення чотирьох малих груп або трьох груп по чотири студенти.

У малій групі студенти мають можливість ділитися думками з приводу навчального завдання і задавати один одному уточнюючі запитання, що полегшує засвоєння матеріалу кожним студентом. Іноді для повного розуміння якого-небудь досліду важливо вислухати декілька точок зору. Висловлюючи власні думки і пояснюючи один одному ті або інші положення, студенти швидше і легше засвоюють навчальний матеріал, закладений у лабораторному досліді. Серед інших факторів, які враховуються нами під час визначення розміру груп, були академічні і соціальні уміння студентів, кількість часу, яка відводиться для спільної роботи, характер лабораторного досліду і обсяг навчального матеріалу [8].

Соціально-психологічні дослідження групової динаміки і педагогічна практика свідчать, що в одній малій групі недоцільно об'єднувати студентів, які є психологічно несумісними або, навпаки, близькими дру- 
зями. Під час організації групової навчальної діяльності студентів ми виходили 3 того, що малі навчальні групи необхідно формувати з обов'язковим дотриманням двох критеріїв: психологічної сумісності членів малої групи і врахування навчальних можливостей студентів. Дотримання зазначених умов забезпечує дієвість та ефективність групової навчальної діяльності. Перший критерій враховується за допомогою прийому добровільного входження студентів до складу конкретної групи [1].

У процесі формування малих груп враховуються також реальні навчальні можливості студентів. Аналіз психолого-педагогічної літератури свідчить, що гетерогенні групи, які складаються з різних за здібностями і навчальними можливостями студентів, мають низку переваг перед гомогенними: забезпечують слабшим студентам можливість звертатися за до- помогою до сильніших, більш здібні студенти виступають прикладом для слабших, поліпшують загальний інтелектуальний фон, своєю більшою начитаністю збагачують знання всієї групи [4].

Висновок. Груповий метод є продуктивною організаційною формою хімії. За умов застосування цієї форми навчання удосконалюються навички логічного мислення і розуміння, в процесі мовлення розвиваються навички розумової діяльності, включається робота пам'яті, йде мобілізація та актуалізація попереднього досвіду і знань, кожен студент відчуває себе розкуто, працює в індивідуальному темпі, підвищується відповідальність не тільки за свої успіхи, а й за результати колективної праці, формується адекватна самооцінка особистісних якостей студентів, власних можливостей і здібностей.

кові записки НДУ ім. М. Гоголя. Психолого-педагогічні науки. -2012. - № 1. - С. 81-87.

6. Гейко I. Інтерактивні форми і методи навчання / I. Гейко // Науково-методичний освітянський часопис “Світло”. -2002. - № 3.-C. 51-53.

7. Лазаренко Н. Ю. Методика організації групової навчально-пізнавальної діяльності студентів на заняттях з практикуму в навчальних майстернях з технології приготування страв / Н. Ю. Лазаренко // Оновлення змісту, форм та методів навчання і виховання в закладах освіти: Збірник наукових праць. Наукові записки Рівненського державного гуманітарного університету. - 2012. - Випуск 3 (46). C. 107-111.

8. Уваров А. Ю. Кооперация в обучении: групповая работа // Учитель и ученик: возможность диалога и понимания / А. Ю. Уваров; под. общ. ред. Л. И. Семиной. - М. : Бонфи, 2002. -408 c. 